\title{
音像移動誘発電位の臨床的研究
}

\author{
東京医科大学耳咽喉科学数空（主任：船坂宗太郎教授） \\ 飯侬尚久
}

\section{CLINICAL STUDY OF TIME-SHIFT EVOKED POTENTIALS}

\author{
NAOHISA IIZUKA, M.D. \\ Department of Otolaryngology, Tokyo Medical College, Tokyo
}

\begin{abstract}
Changing the interaural time difference (ITD) of continuous band noise applied to both ears causes a shift in the perceived lateralization of the noise and evokes the special potentials called "time-shift evoked potentials (TPEPs)". These potentials consist of a positive-negative-positive complex, like a slow vertical response (SVR). Each peak latency of this potential, however, was about $20 \mathrm{msec}$ longer than in the SVR. Testing of 45 volunteers with normal hearing revealed that the feature of this response matched the hearing function test results of detecting lateral position of a sound image. Therefore it could be useful as an objective testing for the hearing function of sound latelization.

The following were established as the conditions for use, in clinical practice : time difference between ears : $0.7 \mathrm{msec}$; sound intensity : $30 \mathrm{~dB} \mathrm{SL}$ at $500-\mathrm{Hz}$ band noise ; stimulus interval : 3.0 sec.; and potential recording from $\mathrm{C} z$ on the scalp. This response was tested in 29 cases of hearing disorders ( 14 cases of inner ear deafness. 2 cases of tinnitus without deafness, 6 cases of peripheral vertigo, 5 cases of intracranial disease, 1 case of functional hearing loss, 1 case of head trauma), and the results were compared with those of the directional hearing test, auditory brainstem response $(A B R)$, and SVR, by using the chi-square test. The results of the directional hearing test and $A B R$ were shown to be correlated with this ERP, and SVR was shown to be independent of it. Thus, it was concluded that this potential is useful as a clinical test.

The significance of the conclusions is explained on the basis of Berjeik's theory.
\end{abstract}

Key words : 両耳間時間差, 音像定位, 音像移動誘発㧘位

聴筧誘発反応，時間差・强度差補完

A $99-0054-10522$

\section{学}

外界の音を両耳て聴取すると，その音源方向を認識 することができ，これを方向感現象という。この機能 は左右耳で同時に聴取された情報の有する両耳間の時 間差 (interaural time difference, ITD) と強度差 (interaural intensity difference, IID) が膇内で正しく 処理されていることを必要とする。したがって，方向 感機能は聼賞中枢機能の模奋法として応用されてい る. 方向感現象には聴空間における音源定位と頍著内
における音像定位に二大別されるが、後者はITDと IID を別個に変化させることができるために，臨床検 査法としては有用てある。

音像定位による方向感検查法は，本邦においてもそ の基碳的および臨床的研究をみるが，これらはすへてて 愳觉心理学的方法によるものである．最近，海外に扔 いて, Halliday", Ungan 2), McEvoy ${ }^{314)}$, Jones ${ }^{(5)} ら は$ ITD を急滶に変化させて音像を移動させると特有な

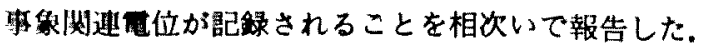




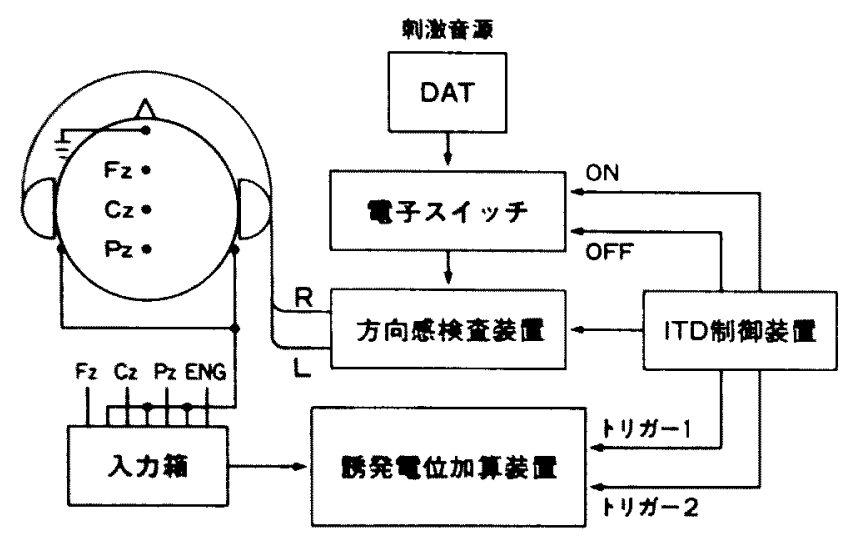

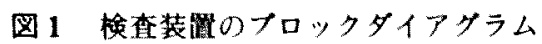

本邦においてはいまだ報告例をみないが、このような 㫣位㚆動が容易に記録されるならば促来の聴覚心理学 的方法による諸特性上照合することは興味深く、また，

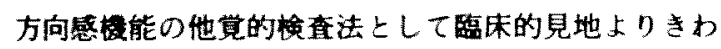
めて有用性が高い。

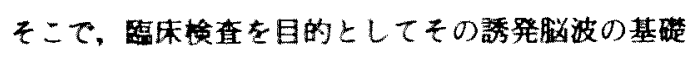
的性而方よU臨床応用について研究した，以下この音 像移娌に伴う誘発電位を「音像移動電位」と呼称して 報告する。

\section{研究方法}

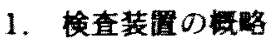

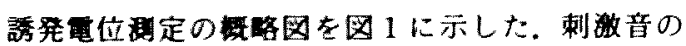
ITD 作製には方向感娭查装理（リオンTD-1 型）を用 い，2個のイヤホンにより瞕取させた。本装碰はITD

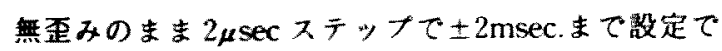
きる。一方，IIDは 1 侽は $5 \mathrm{~dB}$ ，対側は $1 \mathrm{~dB}$ ステッフ

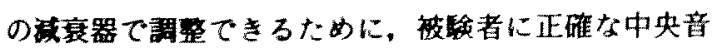
像を成立させることがでる。蚞直音はオージオメー 夕(リオンAA-70) 付属のマスキング雓音を中心周波 数別にあらかじめデジタオージオテープレコーダ (DAT)に録音し，方向感装固に外部入力した。带域揌 波雑音 (以下 BN と路称) の中心周波数は， $250 \mathrm{~Hz}$ ， $500 \mathrm{~Hz}, 1000 \mathrm{~Hz}, 2000 \mathrm{~Hz}, 4000 \mathrm{~Hz}$ の 5 周波数である が，主に $500 \mathrm{HzBN}$ を使用した。誘発電位の測定には シクナルブロッセッサ内藏の誘発電位測定装置 (NEC Synax 1100) を使用した。堌幅器の帯域蝠は時定数 0.3 秒，商域遮断周波数は $100 \mathrm{~Hz}$ に設定した。模查音発生 は、テジタルパルス発信器ちよひ㧘子スイッチにより 外部より制御され，あらかじめ設定されたプログラム により，一定時間間用て連続模査音のITDを 0 と任意
の没定時間差（以下 $\Delta \mathrm{T}$ と略称）に交互に切り替える ものでる。この切替と同時に加算器をトリガーする ことで，音像が外側方向および正中方向に偏倚する場 合の 2 種の事象関連雨位を得られるよう設定した。音 像切り替えは原則として 3.0 秒または 4.5 秒に 1 回と し，加算回数は30回とした。脳波誘过は銀一塩化銀血 電極を用い，接触抵抗を $5 \mathrm{k} \Omega$ 以下とし，七ロイジン固 定した。電極位置は関電極は $\mathrm{Fz}, \mathrm{Cz}, \mathrm{Pz} の 3$ 点, 不 関電極は両耳垂で連結し，接地電極を前額部においた。 眼睑眼球運動によるアーチファクトを除去するために 同時にENG 記録し，大きな動嵒が混入した記録は 自動的に加算より除外した。加算脳波の分析時間はト リガー前 $100 \mathrm{msec}$ より $800 \mathrm{msec}$ とし、 500 ボイントの サンプリング点数で記録した後に25ポイントのスムー

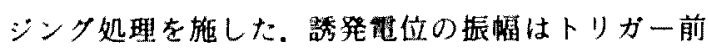

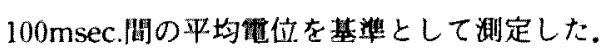

2. 测定の手㮌

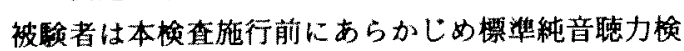
査わ上び方向感機能㭘查を施行した。方向感検查は， 既発表早7)の手順に従いタイアル法抢よび自記法によ り $500 \mathrm{HzBN}, 30 \mathrm{dBSL} の$ 検查音について両耳間時間 差に関する音像移動弁別域值を测定した。 また。音像 移動電位測定の前に, 電極位置 $\mathrm{C} z$ において $500 \mathrm{HzBN}, 30 \mathrm{dBSL}$ のバースト音（持続時間 $350 \mathrm{msec}$, 立ち上がり・立ち下がり時間 $15 \mathrm{msec}$.)によ 万聴性䜌反応 (以下SVR と略) を音像移動電位と同一 の条件で測定した。さらに難聴症例に対しては同じく $\mathrm{C} z に お い て ク リ ッ ク$ 音刺激 $90 \mathrm{dBnHL}$, 刺激間隔は $50 \mathrm{msec}$, 加算回数 1000 回, 解析時間 $10 \mathrm{msec}$. フィル夕 一の通過帶域 $50 \sim 3 \mathrm{kHz}$ の条件て ABR を測定，記録 


\section{I 僡性綬反応}

\section{音像移動の棌式}

\section{A 法：正中一侢倚 \\ B 法：偈倚 $\rightarrow$ 正中}

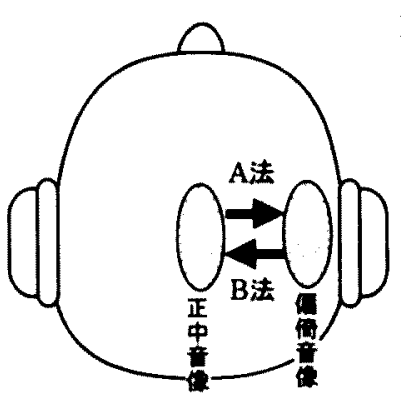

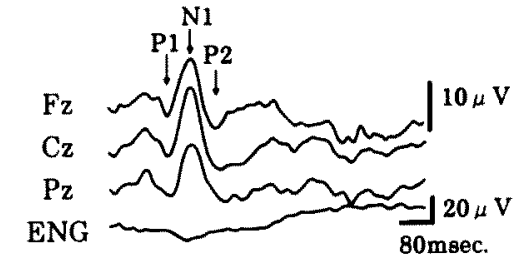

II 音像移趿能発亚位

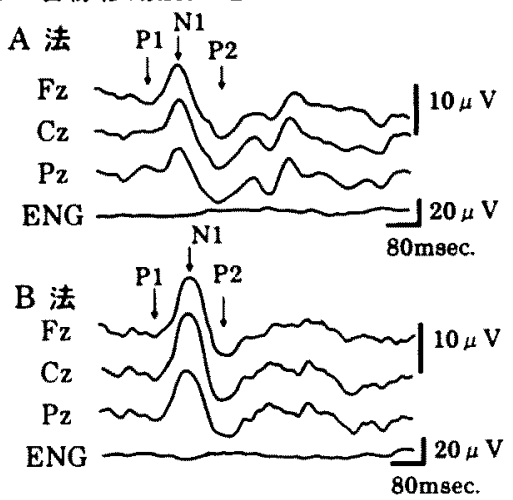

图 2 音像移動の様式と実際の波形

した，音像移動電位測定に際しては被模者を仰卧位と

し，まず换㚗音を $\Delta \mathrm{T}=0$ の状態で1側耳に $30 \mathrm{dBSL}$ でえ，音像が頭蓋正中に成立するように他側耳を $1 \mathrm{~dB}$ ステップで微調節した状態を両耳間強度美（以下 $\Delta \mathrm{I}$ と記す) =0とみなし，この状笖を基準の正中音像

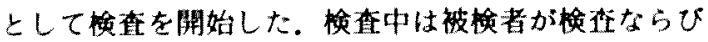
に音像移動を自党しないように芜曋をさせ，いわゆる “ignore"の状照とした。各剌酸条件の模在終了後。被

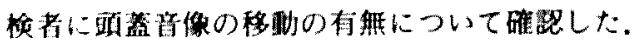

3. 对象

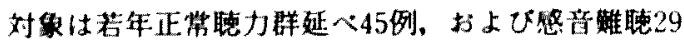
例である。群細は後述する。

1. 正常群

1) 带型波形

图 2 左に形盖内音像位疽の移動棣式を示した。すな わち, 正中音像上り左耳が $+0.7 \mathrm{msec}$. 遈延した場合 $(\Delta \mathrm{T}=+0.7 \mathrm{msec}$. $)$ の頭蓋内音像の移動を示してお り，音像は正中上り右側頭部に偏倚し，この際音像移 助致位が得られ，これを $\mathrm{A}$ 法と称した。次に，この状 萔から再げ $\Delta \mathrm{T}=0$ とすると, 音像は再び正中に㞍り この時点で別個の音像移娌兆位が得られ，これをB法
と称した。右图は $\mathrm{Fz}, \mathrm{Cz}, \mathrm{Pz}$ より缽鼻した $\mathrm{SVR}$ およ ひA，Bの2法に上り得られた音像移動電位の典型的 波形である. 3 者とも相似の 3 相性の波形が得られ， 本論文ては，すへててピークをP1，N1，P2 とした。 ずれも ENG てい眼球证動を発生せず，誘発波とは無 网係である。この音像移野位が、音像切り換元時に

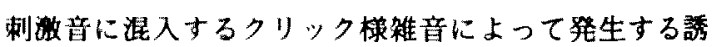
発位ではないことを確琶するために，500HzBNの

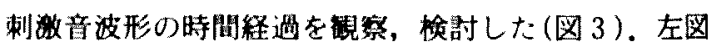
は $\mathrm{A}$ 法の場合，右四は B 法の場合である.前者は $\Delta \mathrm{T}=$ 0 の状態から $\Delta \mathrm{T}=+0.7 \mathrm{msec}$. に相当する波形が左 耳に插入され，相対的に右耳の波形が先行するため， 図2のように音像は右側方に偏倚し，後者は逆に $\Delta \mathrm{T}=-0.7 \mathrm{msec}$. に相当する波形が削除されるために 再び $\Delta \mathrm{T}=0$ となり，音像蛙正中に戻る。この㨉入，削 除に際して図にみられるごとく，視觉的には波形上に 雑音, すなわちアーチファクトの混入はなかった。次 に，聴筧的にクリックの影整をみるために，可変チャ ネルの刺瀿音のみを50dBSLで単耳に聴取させ，測定 したところ、クリック音による誘発波は生じなかった。

2）测定部位別の波形特性

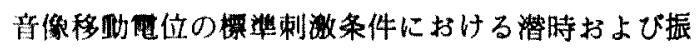
帽を頚浿上の 3 点においてて, SVRのそれらと比較, 検 


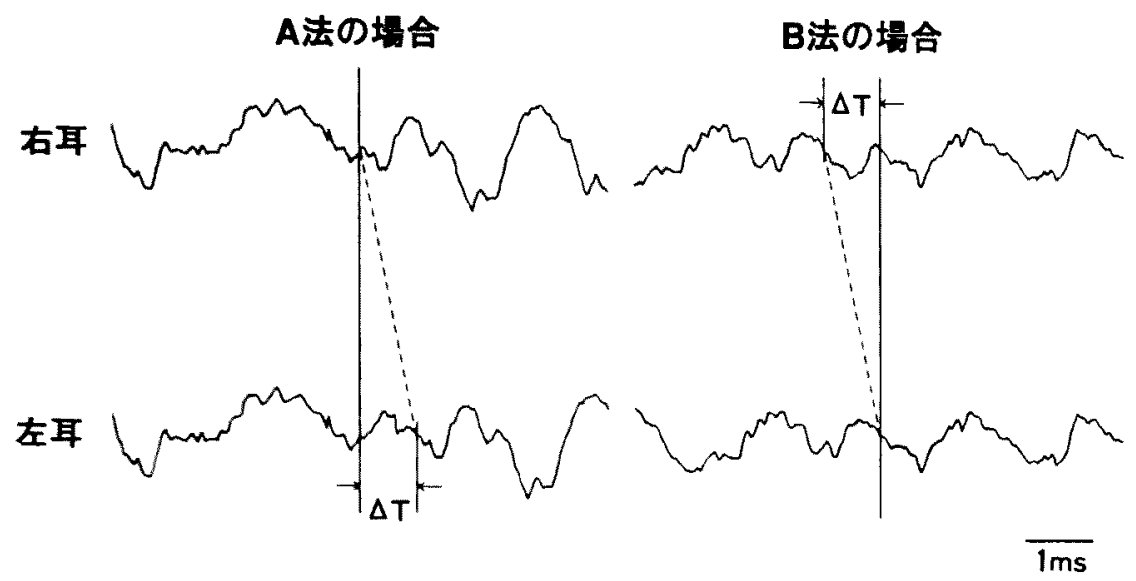

图 3 音像切替時の刺湤音波形心時間経過

討した。菠梌者は正萦者18名てある。

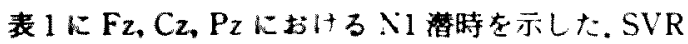

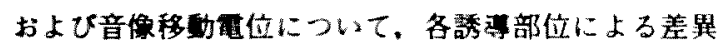

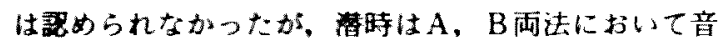
像移䇴位O方加 SVR

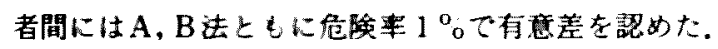
また，A法とB法について平的䛧を比㜞すると、A法

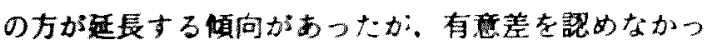
t.

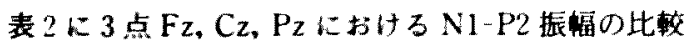

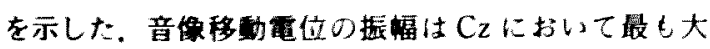

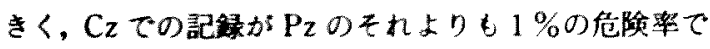

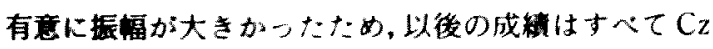

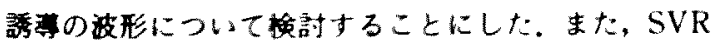

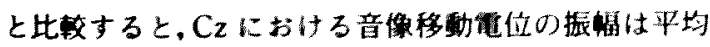

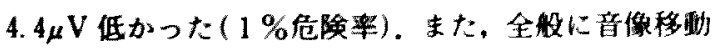

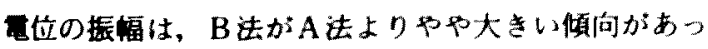
たが，有盖着は記めなかっだ。

3）音像移副至位心関する日子

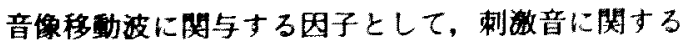
以下の 4 項目について, 波形出現の有無を視察的に評 洒した。評価は採点法とし，波形が非常に上く出現(3)， 出現(2)，どちらともいえず(1)，出現せず(0)の 4 段倩科 洒とした。各条件下の個々の波形について 3 人の㭲者 が別個に評価し，その平均点を求めた。また，音源は すへて带域迹波程音を使用し，負荷条件は目標のバラ メータ以外は前記に従った。

(1) 中心周波数

刺放音の周波数に成する影管をみるために両耳間時
家 1 N1 茜時の比較 $(n=18)$

\begin{tabular}{ccccc}
\hline & \multirow{2}{*}{ 㯖性楥反応 } & \multicolumn{3}{c}{ 音像移㽖誘発電位 } \\
& & A 法 & B 法 \\
\hline $\mathrm{F}_{2}$ & $115.4 \pm 12.24$ & $138.2 \pm 16.69$ & $133.0 \pm 10.03$ \\
$\mathrm{Cz}$ & $114.6 \pm 12.29$ & $136.5 \pm 15.94$ & $131.8 \pm 10.76$ \\
$\mathrm{Pz}$ & $114.8 \pm 14.10$ & $137.1 \pm 16.32$ & $130.4 \pm 11.91$ \\
\hline
\end{tabular}

単位: msec.

表 2 N1-P2 振幅の比較 $(\mathrm{n}=18)$

\begin{tabular}{|c|c|c|c|}
\hline & \multirow{2}{*}{ 聴性悢反应 } & \multicolumn{2}{|c|}{ 音像移動誘発電位 } \\
\hline & & A 法 & B 法 \\
\hline $\mathrm{Fz}$ & $11.8 \pm 4.09$ & $8.0 \pm 3.18$ & $8.9 \pm 4.42$ \\
\hline $\mathrm{C} z$ & $13.3 \pm 4.07$ & $8.1 \pm 3.57$ & $9.6 \pm 4.48$ \\
\hline $\mathrm{Pz}$ & $10.4 \pm 3.44$ & $6.8 \pm 2.74$ & $6.47 \pm 2.89$ \\
\hline
\end{tabular}

間差 $\Delta \mathrm{T}=+0.7 \mathrm{msec} . \sigma 一$ 定とし, 剌新の中心周波 数別，士故 $5250 \mathrm{~Hz}, 500 \mathrm{~Hz}, 1000 \mathrm{~Hz}, 2000 \mathrm{~Hz}$, $4000 \mathrm{~Hz}$ の 5 周波数别にSVR および音像移動爾位を 湖定した。

图 4 k舆型的な 1 例を示した，上段はSVR，下段は A 法による音像移動電位である。各波形の下にN1-P2 の据幅 $(\mu \mathrm{V})$ を表示した，SVRはすへての刺激音に対 して出現し，中心周波数 $1000 \mathrm{~Hz}$ 以上では振幅が縮小 した。一力，音像移䖝電位は中心周波数 $500 \mathrm{~Hz}$ が振幅 取大で，1000 Hzてはかなり縮小，2000 $\mathrm{Hz}$ 以上ではま ったく出現しなかった。 


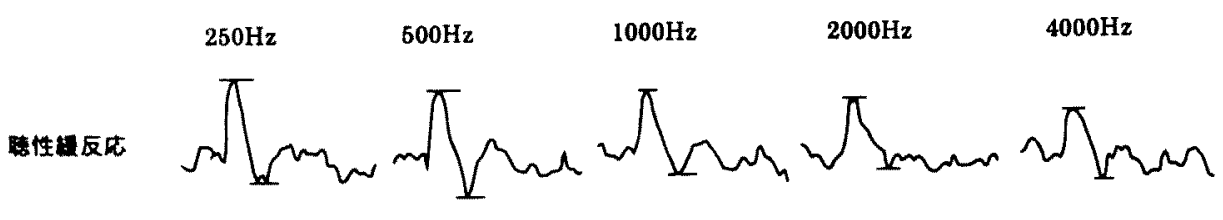

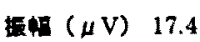

18.2

13.6

11.5

11.7

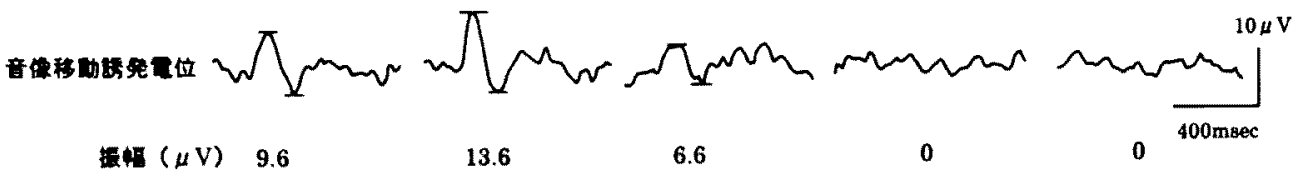

図 4 周波数別の解発波

次に，被惨者10名について，音像移䵢西位の波形出 現に对する伻価值の平均を表 3-Iに示しだ. A，B車 法についてほは同㥞の衦価値を示し, $500 \mathrm{~Hz}$ で最大, $2000 \mathrm{~Hz}$ 以上ては0でっった。すおち、因4に示した 典型的な波形の振福測定值と評価平均值はよく一致し ていた。

(2) 両耳間時間差

被娭者13名に対して，両耳間時間差による変動を同 様に評価した。 $\Delta \mathrm{T}$ を $0.08,0.1 ， 0.2 ， 0.3 ， 0.5$, $0.7 \mathrm{msec}$.の 6 条件について検郡すると, $0.1 \mathrm{msec}$.の 場合上り波形の出現を認め、評価值は時間差の拉大と ともに增大し，0.7msec．において曼大となった．A， B両法の間に一定の傾向はみられなかった（表 3-II）.

(3) 刺敏音の强さ

被惨者 6 名について，中心周波数 $500 \mathrm{~Hz}, \Delta \mathrm{T}$ ：

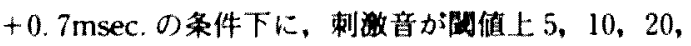
$30,40,50 \mathrm{dBSL}$ の 6 条件下の刺㴚レベルにおける音像 移野里位について科価した，刺制音レベルが大になる につれて評価值は大となり，30dBSLの堵合に服大き らにレヘルが上显すると、硬価值はやや低下した（表 3 - III).

\section{(4) 刺激㫮間降}

被枱者 5 名について，前項と同じ条件下における皆

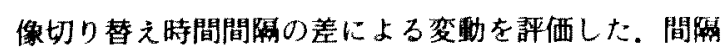
が1.0，1.5，2.0，3.0，4.5secの5条件についてみる と, 1.0sec では評価值はやや小さく，3.0 sec，4.5 sec において曼大となった（表3-IV）。

4）特殊条件下の潜時および波形特性

(1) 時間差変動の場合

被娭者12名について，周波数 $500 \mathrm{HzBN}$, 强さ

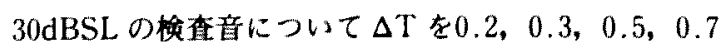

衰 3 各パラメータ別のスコア

\begin{tabular}{cl|llllll}
\multicolumn{1}{|c}{} & 中心周波数別スコア & & \multicolumn{2}{c}{$(\mathrm{n}=10)$} \\
\hline & & 周波数 $(\mathrm{Hz})$ & 250 & 500 & 1000 & 2000 & 4000 \\
& & & & & & \\
\hline A & 法 & 2.5 & 2.9 & 1.7 & 0 & 0 \\
B & 法 & 2.4 & 3.0 & 1.7 & 0 & 0 \\
\hline
\end{tabular}

\begin{tabular}{|c|c|c|c|c|c|c|c|}
\hline \multirow{2}{*}{\multicolumn{2}{|c|}{$\frac{\text { II 両耳間時間差 }}{\Delta \mathrm{T} \text { (msec.) }}$}} & $(\Delta \mathrm{T}$ & & בオ & & \multicolumn{2}{|c|}{$(n=13)$} \\
\hline & & 0.08 & 0.1 & 0.2 & 0.3 & 0.5 & 0.7 \\
\hline A & 法 & 0 & 0.4 & 1.8 & 2.3 & 2.2 & 2.9 \\
\hline B & 法 & 0 & 0.2 & 1.3 & 2.5 & 2.6 & 2.9 \\
\hline
\end{tabular}

\begin{tabular}{|c|c|c|c|c|c|c|c|}
\hline \multicolumn{6}{|c|}{ 剌使音の強さ別スコア } & \multicolumn{2}{|c|}{$(n=6)$} \\
\hline & & 5 & 10 & 20 & 30 & 40 & 50 \\
\hline A & & 0.5 & 1.3 & 2.3 & 3.0 & 2.8 & 2.5 \\
\hline B & 法 & 1.0 & 1.7 & 2.3 & 3.0 & 2.8 & 2.5 \\
\hline
\end{tabular}

\begin{tabular}{|c|c|c|c|c|c|c|}
\hline \multicolumn{5}{|c|}{ 刺間別スコア } & \multicolumn{2}{|c|}{$(n=5)$} \\
\hline & & 1.0 & 1.5 & 2.0 & 3.0 & 4.5 \\
\hline A & 法 & 2.2 & 2.5 & 2.6 & 3.0 & 3.0 \\
\hline B & 法 & 1.8 & 1.3 & 2.4 & 3.0 & 3.0 \\
\hline
\end{tabular}

msec.の 4 条件下におりる N1，P2 潜時と N1-P2 振幅 を表 $4 \mathrm{a}, \mathrm{b}$ に示した， $\Delta \mathrm{T}$ の変化により音像位置は変 娌するが，N1，P2 潜時は有意密はなかった。

一方，N1-P2 振幅は， $\Delta \mathrm{T}$ が小になると維小し， 0.7 
衰 $4 \Delta \mathrm{T}$ による潜時および振幅 $(n=12)$

a) N1，P2 潜時

\begin{tabular}{ccccc}
\hline$\Delta \mathrm{T}$ (msec.) & 0.7 & 0.5 & 0.3 & 0.2 \\
\hline $\mathrm{N} 1$ 潜時 & $\mathbf{1 3 6 . 5 \pm 1 0 . 7 3}$ & $139.7 \pm 9.89$ & $134.9 \pm 11.78$ & $147.4 \pm 8.93$ \\
$\mathrm{P} 2$ 潜時 & $219.3 \pm 8.64$ & $230.2 \pm 27.41$ & $231.8 \pm 17.24$ & $231.8 \pm 17.24$ \\
\hline
\end{tabular}

b) N1-P2 振幅

\begin{tabular}{ccccc}
\hline$\Delta \mathrm{T}$ (msec) & 0.7 & 0.5 & 0.3 & 0.2 \\
\hline 振楅 $(\mu \mathrm{V})$ & $9.9 \pm 3.26$ & $8.4 \pm 2.41$ & $8.2 \pm 2.78$ & $8.2 \pm 2.78$ \\
\hline
\end{tabular}

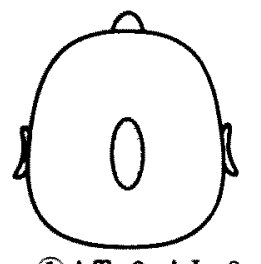

(1) $\Delta \mathrm{T}=0 . \Delta \mathrm{I}=0$

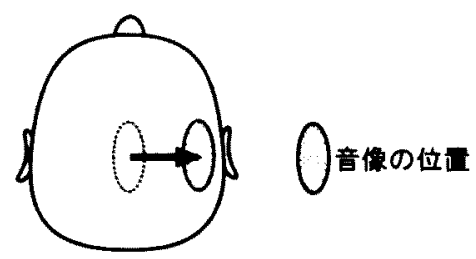

(2) $\Delta \mathrm{T}=+0.7 \mathrm{msec}$
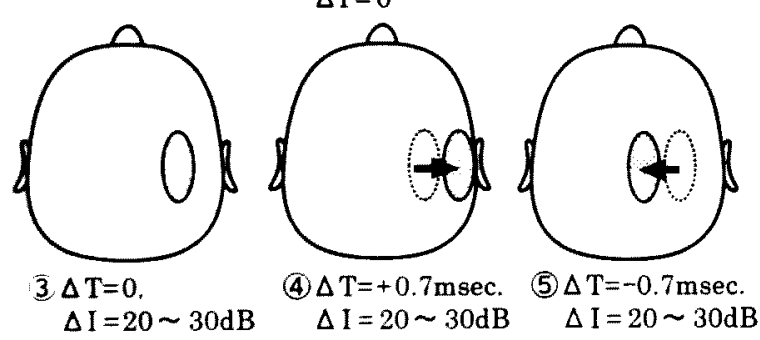

图 5 音像移㽖の槏式

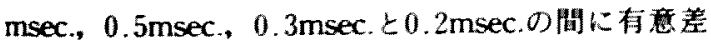
(危险率 $1 \%$ ) を諟めた。

(2) 㣂奇音像の㳟合

前項の $\Delta \mathrm{I}=0$ の埸台と異なり，

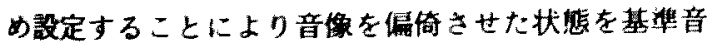
象とし，更に前述と同じ方法て $\Delta T$ を変化させた䀛台 の音像移较位について㛟討した。

音移和㫣位は图5のごとく湖定した。まず，(1)図 2 と同しく $\Delta \mathrm{T}=0, \Delta \mathrm{I}=0$ のとさ音像は䫒盖正中に ある.つきに、(2) $\Delta \mathrm{T}=0.7 \mathrm{msec}$ に変化すると, 音像は 右耳介付近に移娌し，图6に示す上うに，园20A法 にあたる波形が得られ、これを波形 $a$ とした。(3)右耳 を $\Delta \mathrm{T}=0$ のまま $\Delta \mathrm{l}=20 \sim 30 \mathrm{~dB} に$ 変化すると，音像

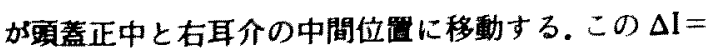
20〜30dBの条件下で5に(4) $\Delta \mathrm{T}=+0.7 \mathrm{msec}$.を加 えると, 自覚的に，上り側方に桷掎する音像を生し，

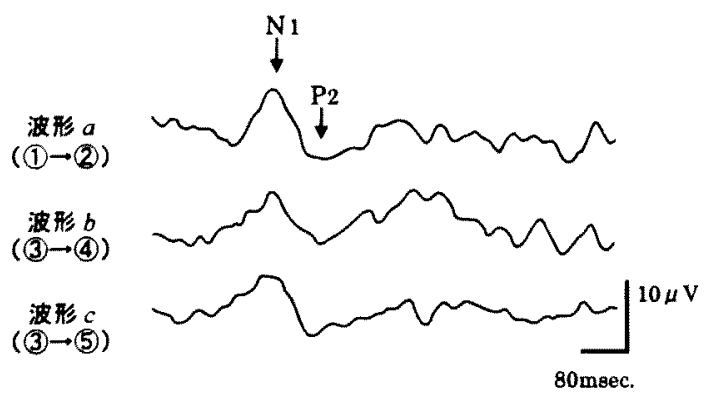

図 6 実際の波形

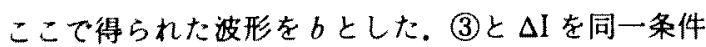
の音像位睡て(5) $\Delta \mathrm{T}=-0.7 \mathrm{msec}$ に変化すると音像は (3)の位畾よりゃや正中奇りに移動し，同㴍に波形 $c$ が 記録された。

波形 $a ， b ， c$ 比較すると，すぶて相似閔係であ 
表 5 波形ごとの潜時および振幅 $(n=15)$

\begin{tabular}{c|ccc}
\hline & $\begin{array}{c}\text { 波形 } a \\
(1) \rightarrow(2))\end{array}$ & $\begin{array}{c}\text { 波形 } b \\
((3) \rightarrow(4))\end{array}$ & $\begin{array}{c}\text { 波形 } c \\
(\text { (5) } \rightarrow(6))\end{array}$ \\
\hline $\begin{array}{c}\text { N1 潜時 } \\
(\mathrm{msec})\end{array}$ & $131.1 \pm 8.8$ & $132.7 \pm 9.7$ & $133.2 \pm 8.7$ \\
$\begin{array}{c}\mathrm{P} 2 \text { 潜時 } \\
(\mathrm{msec})\end{array}$ & $216.3 \pm 17.4$ & $214.9 \pm 14.4$ & $221.5 \pm 23.7$ \\
$\begin{array}{c}\mathrm{N} 1-\mathrm{P} 2 \text { 振愊 } \\
(\mu \mathrm{V})\end{array}$ & $9.5 \pm 3.11$ & $6.6 \pm 1.66$ & $6.7 \pm 2.44$ \\
\hline
\end{tabular}

衰 6 対象症例の内即 $(n=29)$

\begin{tabular}{|c|c|}
\hline 垁 患 名 & 症例数 \\
\hline 内耳性難德 & 14 (例) \\
\hline 無賆㯖性耳鳴 & 2 \\
\hline め $ま い$ & 6 \\
\hline 暊蓋内疾患 & 5 \\
\hline 機能性難德 & 1 \\
\hline 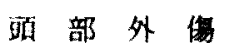 & 1 \\
\hline
\end{tabular}

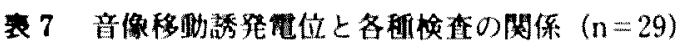

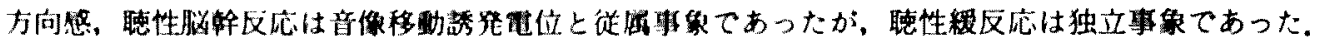

\begin{tabular}{|c|c|c|c|c|c|c|c|}
\hline \multirow{2}{*}{()$: \%$} & & \multicolumn{2}{|c|}{ a) 万向毇 } & \multicolumn{2}{|c|}{ 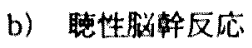 } & \multicolumn{2}{|c|}{ c）聴性䌅反応 } \\
\hline & & 異莹 & 正常 & 異常 & 正常 & 異常 & 正常 \\
\hline \multirow{3}{*}{ 音像移動誘発笔位 } & 異常 & $\begin{array}{l}4 \text { (列) } \\
\text { (14) }\end{array}$ & $\begin{array}{c}3 \\
(10)\end{array}$ & $\begin{array}{c}4 \\
(14)\end{array}$ & $\begin{array}{c}3 \\
(10)\end{array}$ & $\begin{array}{c}2 \\
(7)\end{array}$ & $\begin{array}{c}5 \\
(17)\end{array}$ \\
\hline & 正常 & $\begin{array}{c}3 \\
(10)\end{array}$ & $\begin{array}{c}19 \\
(66)\end{array}$ & $\begin{array}{c}0 \\
(0)\end{array}$ & $\begin{array}{c}22 \\
(76)\end{array}$ & $\begin{array}{c}1 \\
(3)\end{array}$ & $\begin{array}{c}21 \\
(73)\end{array}$ \\
\hline & & \multicolumn{2}{|c|}{$\chi^{2}: 5.4891^{*}$} & \multicolumn{2}{|c|}{$\chi^{2}{ }_{s}: 14.5828^{*}$} & \multicolumn{2}{|c|}{$\begin{aligned} x_{\mathrm{s}}^{2} & : 3.3051 \\
x_{0.01}^{{ }_{0.01}}: & 6.63490 \\
\chi_{0.05}^{2} & : 3.84146\end{aligned}$} \\
\hline
\end{tabular}

るが、被唡者15名についてこれらの誘発波形の N1，P2 潜時と N1-P2 振幅電位を测定した（表 5)。N1とP2 の潜時はそれぞれ約 131〜133msec.と215〜222msec. てあり，各波形に有意差はなく音像の位睓帘化に上る

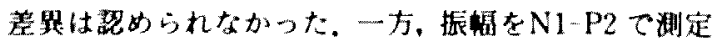

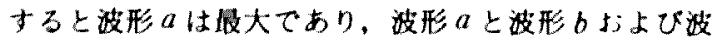

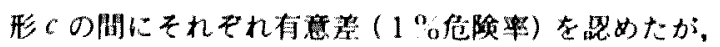
波形 $b 、 c$ 閒に有意差は存在しなかった。

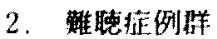

1) 刺音の条件

前述の正常例について検討した結果，臨床症例に対 する測定条件は以下のごとく決定しだ。すなわち，音 の種類は $500 \mathrm{HzBN}$, 強さは原則として $30 \mathrm{dBSL}$, 両耳 間時間差は $0.7 \mathrm{msec}$, 剌败間隔は $3.0 \mathrm{sec}$, 加算回数は 原則として30回である。

2）音像移動電位の臨床

对異：オージオクラムが方向感模查の適応条件" 合致した各種の感音難萤計29例（表 6) に対して，万 向感，音像移怔电位，ABR，SVR の諸榙查を施行した。 方法: 音像移㽖的位が出現しない症例が， 7 例 $(24$ \%)存在したため，その出現の有無と他の顺㚗所見と

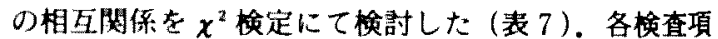
目の異常例とは，音像移助電位では波形が出現しない

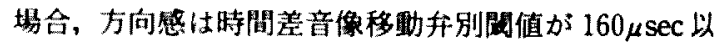
上の埸合"), ABR は I V V 波間潜時が $4.26 \mathrm{msec}$. 以上 の埸合"，SVRては波形が出現しない場合と規定し た.

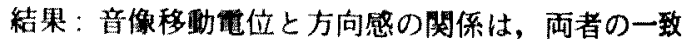
率 $80 \%$ であり， $x^{2} \mathrm{~s}=5.4891$ となり，両者は従属事象

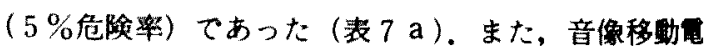
位とABRの両者の一致率は $90 \%$ てあり， $\chi^{2} \mathrm{~s}=$ 14.5828となり両者は従属事象(1\%危険率)てあった。 特にABR の異常例は 4 例全例とも音像移動電位が出 現しなかった(表 $7 \mathrm{~b}$ )。しかし，音像移野雨位とSVR の比較ては一致率は $80 \%$ であったが, $x^{2} \mathrm{~s}=3.3051$ と なり，5\%危険率て両者は独立事象であった（表 $7 \mathrm{c}$ ).

\section{考按}

今回の研究対象となった䐐発电位は本邦における報 告例をみない：この波形は事象闺連雨位の一種でる が，音像移野田位と呼称してまず海外の同租の誘発電

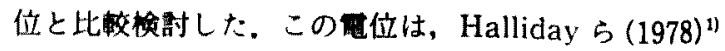


により time shift evoked potentials (TESPs) と命 名され原著として初めて発された。表さの後、今日ま て Ungan ら (1989) ${ }^{\prime \prime}$ \& laterality reversal audiotory evoked potentials (LRAEPs), Paavilainen 5 $(1989)^{101}$ は miss match negativity (MMN) として, またその後, McEvoy ら (1990)", (1991)", Jones ら

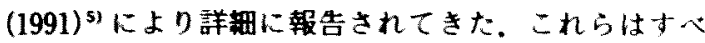
ての音愿または音像の急游な変化に伴って発生する ERPてあるが，刺激方法は多少翼なる。さらに、これ らの報告はすべて正常人を对象とした基整研究である

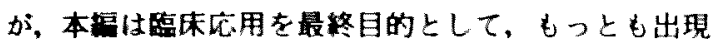
しやすい㜀定法を䖵自に筑した。まず、著者の方法。 波形特性とこれらの諸報告と支比校し，その異同を娭 討した。

\section{1. 洞定方法放上U波形心特佂}

1) 定方法

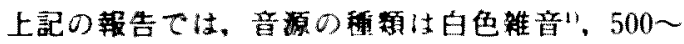

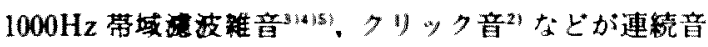
として与えられている。加真回数は50回，64回 ${ }^{21}$,

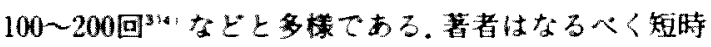
間にもつ上も出現しやすい条件として，基硞的な㛟討

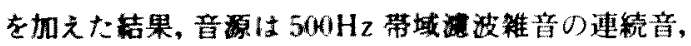

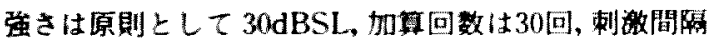
は3.0 $\mathrm{sec}$ の条件を决定した。特に加而问数は従来の報

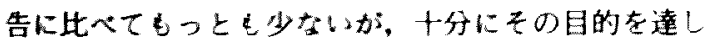
得た。

記錄部位支文嗝により $\mathrm{Fz}, \mathrm{Cz}, \mathrm{Pz}, \mathrm{C}_{3} ， \mathrm{C}$ なな゙よ

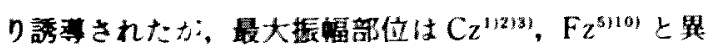
なった。我々も $\mathrm{Fz}, \mathrm{Cz}, \mathrm{Pz} に$ にいて饭尌した結果(表 $1,2), \mathrm{Cz}$ は他の 2 部位に比へて潜時は有意差を银め なかったが、整位がやや禹かったたか原則として C より誘通しだ。

\section{2) 記録波形}

記録波形は图 2 のことく典型的な 3 相性の䌅徐波て

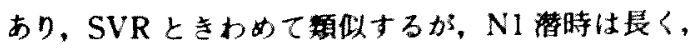
N1-P2 振福は小さい。一般にN1 潜時が各パラメータ の指標となる場合が多いが、我々の測定值した $\mathrm{C} 2 に$ おけろ替時, すなわち $131 \mathrm{msec}$. (B法) 136 msec. (A 法）(表 1)は，刺激条件がもつとも䅡似するMcEvoy $5^{334}(130 \sim 136 \mathrm{msec})$ ，ちよひ Jones ${ }^{51}(130 \mathrm{msec})$ と よく一致し，被らの波形と同一性筫のものと確認され た。一方，刺澈音が連続クリック音または短音の場合， Ungan $5^{2)}(160 \mathrm{msec})$, Paavilainen $5^{10}(150 \mathrm{msec}$.) の値はやや延长してちり，多少性賽を異になる可能性
がある。

記録波形の潜時及び振幅は，音像切り替えの方向に よって異なることが論じられている．著者は中央より 右側方への偏倚を A 法, 逆方向をB法と分類した結果, N1 潜時およびN1-P2 振幅に有意差は認められなか つた(表1)。しかし、これらについては報告者によっ て異なり，潜時はB法の方が長いかか，または短く2， 振擂はB法の方が大きい"，または小さい(214)など，報 告者により一定てない。これは測定法の相連によるこ ともあり, 今後の研究課題と思われた。

2. 万向感と波形の比較

万问忽，特に音像を指標とした聴賞心理学的手法に おけるデー夕と音像移動電位の特性を比較すること は，この波形が方向感の他覚的現象として臨林的に応 用でるるか否かを決定するために必要である。

音像洁両耳間の時間䔺と强度差の相互関係によって 成立するが，両者は互换性があり， time vs intensity trade の関係を示すことが知られているい12n3!この現 象は音像移動電位によっても認められたが（表 5 b)， これについては次項に扔いて詳述する。亦た，両耳時 間差に関しては，検査音の周波数について $1000 \mathrm{~Hz}$ 以 下の場合に音像移動が起こり, $2000 \mathrm{~Hz}$ 以上ではきわ めて判定し難くなり，音像移動弁別閭值は $500 \mathrm{HzBN}^{(6)} ， 600 \sim 850 \mathrm{HzBN}{ }^{(2) 14}$ において最小とな る. 音像移動電位においても同様に, $1000 \mathrm{~Hz}$ 以下のみ

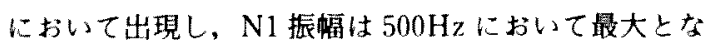
り(図 4), 先の心理学的成結上きわめてよく一致した。 一方，同時に测定したSVRは $250 \mathrm{~Hz} よ り 4000 \mathrm{~Hz}$ ま

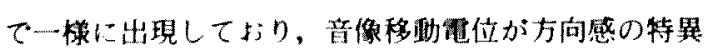

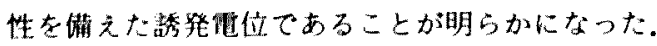

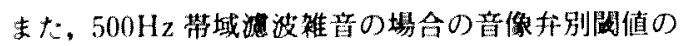
集却限界は $0.08 \mathrm{msec}^{6)}$ であるが，同一音源における

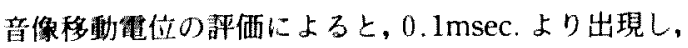
$\Delta T$ の增大とともに評価し易くなり，音像が明らかに 頭蓋正中より耳介周辺に偏筒する $0.7 \mathrm{msec} . の$ 場合に は評価点が最高となった(表 3 一II)。この現象はN1 $\mathrm{P} 2$ 振幅の测定值が $\Delta \mathrm{T}$ の增加とともに高くなり, $0.7 \mathrm{msec}$ において最大値を示すことと一致した（表 4b).すなわち，本波形は $\Delta \mathrm{T}$ の影整を受ける従来の方 向感賞上きわめて密接なものである。この関係は，臨 床応用の成績において， $x^{2}$ 检定の結果，音像移動撆位 とSVR の関保は独立事象である（表 7c）が, 表 7aに 示すごとく，音像移動電位と方向感とは古いに従属事 象である事実が示されだ。これらの現解により，本波 
形の湖定は、“ignore”の状態で施行するため,従来の方 向感測定 ${ }^{25)}$ の他覚的検查法として臨床的にも有用性 のあることが立証された。

\section{3. 波形の成立機序}

音像移動㫣位の成立機序はまだ十分に解明はされて いないが，MMNに類似した機序によるものてあろう

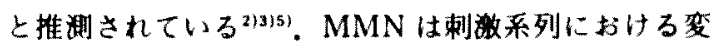
化を自動的に模出する機能を反映するものといわれ

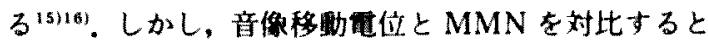
両者はともに刺激系列を“ignore”の状悲で検直する点 は一致しているが、今回の音像移野电位は連繶波によ

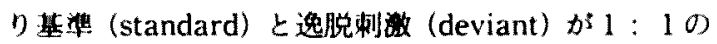
出現事で交互に努化するのに对して，MMNの场合 は、オドボール課睡が利用されること、まだ剌放音は， トーンパーストなどが使用され，さらに本来両制做に より得ら机た別個の波形の減算によって踶祭される波 形であるという相連点がみられる。.Paavilainen ${ }^{(0)}$ は， この方法によって音像および音源の偏倚に对する 2 相 性のMMNを測定し，最大振幅はFzで得られ，潜時 は 100〜200msec. と報告したが，前述の諸報告および 著者の波形と多少異なっており，音像移動電位が MMN そのものとはいえない。

一方, 方向感成立の理論には諸学説がみられるが, すべて㮸幹における れている゙フ21!。そこで，まず音像移動電位の成立機槽 のうち下位中枢について, Bekésy ${ }^{171}$ の説を発展させ たBergeijk ${ }^{2012 n}$ の説に促って考祭した。

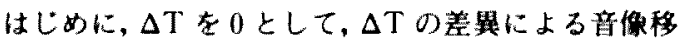

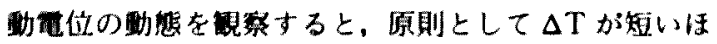

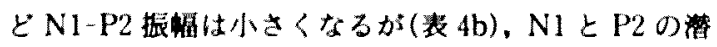
時はほは一定てある(装4a)。一力, 図 5-(3)のこととく $\Delta \mathrm{I}=30 \mathrm{~dB}$ に股定して者像考右側に湖倚させたのち， $\Delta \mathrm{T} 0.7 \mathrm{msec}$.に設定し，右または左耳に先行させた

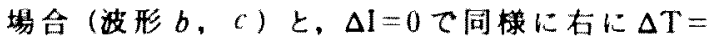
$0.7 \mathrm{msec}$.として先行させた場合（波形 $a ）$ を比較する と，先の表 $4 \mathrm{~b}$ と同様に N1-P2 振愊は $\Delta \mathrm{I}=30 \mathrm{~dB}$ の埸 合（波形 $b ， c$ ) に筝小寸るが(表 5)，N1 と P2 潜時 は先の $\Delta \mathrm{T}$ をバラメータとした場合（表 4a）と同様に ほほ一定てあった(表 5)。この両者の結果を絰合する と，音像移動電位の振幅が縮小寸る晛象は $\Delta \mathrm{l}$ の增最

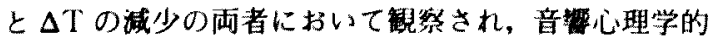
にみられる time vs intensity trade を他视的に示した ことになる、一方,この場合にN1および P20整時は ほとんど変化しない奇異な現象がみられた。これを考
察するために Bergeijk ${ }^{211}$ の仮説を引用した。

すなわち，台形体においては両側の蝸牛神経支配を されてお゙り，その支配は対側に刺激線維，同側に抑制 線維が分布し入力価号によって同時に両側の核に同其 の興简と抑制の発火を左右側より中央に向かって起こ すと仮定されている．図7はこれをモデル化したもの て, 点状部分は興签，斜線部分は抑制された神経紐胞 群を面稿で示した。図の番号は図 5 の番号の音像に相

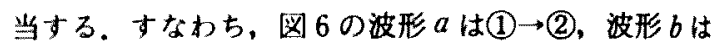

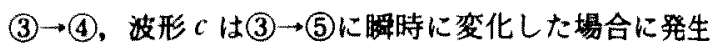
するが，図７においては(1)は $\Delta \mathrm{T}=0, \Delta \mathrm{I}=0$ の場合で あり，左右の興第する核の面䅡 $\mathrm{a}$, a'は等重であるため に，両側の外側毛带を上向する情報量は等しく音像は

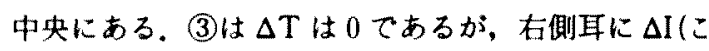

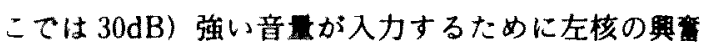

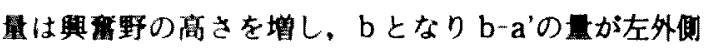
毛带を、a'が右外側毛带を上向し左右差を生じるため に音像は右側に偏倚する。次に $\Delta \mathrm{T}$ の量に比例して， $\chi$ の面積か增城するとみなすをき，図 7 の(2), (4), (5) の $\Delta \mathrm{T} は 0.7 \mathrm{msec}$. と一定でるために波形 $a, b, c$ はすべて左右の核に $\chi$ の面積変化を生じたときに発 生する.この際，波形振幅は変換前，すなわち(1)，(3)

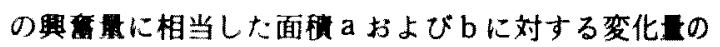

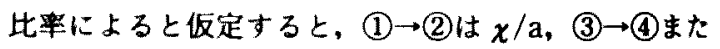
は(5)は $\pm \chi / \mathrm{b}$ となるた好変化率は後者が小となり, 波 形 $a$ に比へて波形 $b ， c$ はほ中等しく小となる。一方,

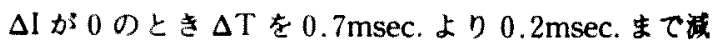
少させた表 $4 \mathrm{~b}$ は $\chi$ の㨔少とともに $\chi / \mathrm{a}$ が次第に娍 少していくために，先の波形 $b ， c$ と同様に振幅が娍 少する。またこの振幅の大小は聴賞心理学的な音像 の倔倚度とよく一致するために音像偏倚の感筧量の決 定因子といえよう。

それては、この埸合に潜時が一定てあるのは何故て

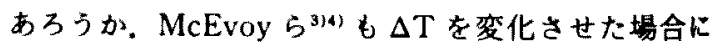
音像移動雨位のN1 振幅は恣動するが, 潜時は変化し ないと報告し, Paavilainen ら ${ }^{10)}$ もMNにおいても 同様の所見を示している，音像移動電位仕SVRお゙ び聴覚誘発磁界 22123)の $\mathrm{N}_{100} お よ ひ ゙ N_{1 m}$ よりもやや長 い潜時を有することが特徽である。まず，下位中权に 関しては， $\Delta \mathrm{T}$ の情報が上オリーフ核を横切る時間は $2 \mathrm{msec}$.といわれているため20)，下位中权における消䖭 時間は鏵少であり、潜時の帘動および差異を説明し得 ない，さらに，音像移野西位は“ignore”の状䈍て記錄 されるが、籍を锁むなどの党醒レベルの維持が必要 


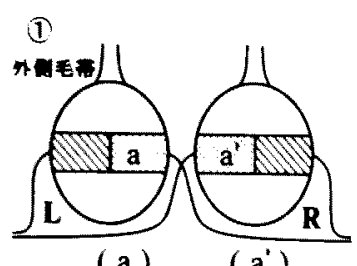

(a)

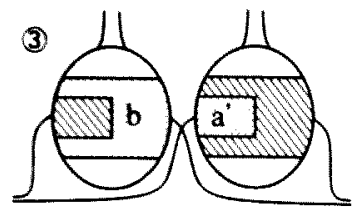

(b) (a')
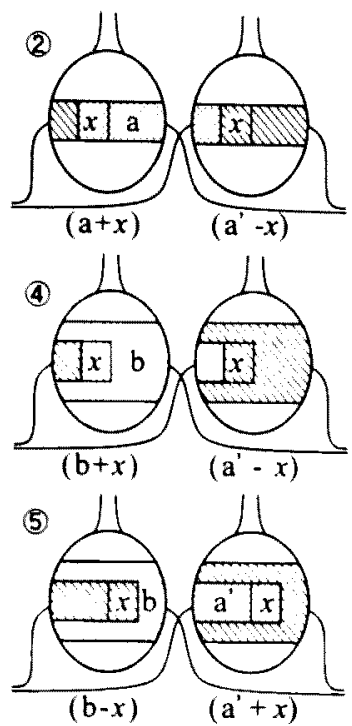

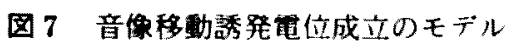

左右台形体核の神経湅胞群の状態を示す。点状部 行は興霄，斜線部分は抑制神経領域をあらわす。

であり, drowsy の状㤰では記録できない。また、音像

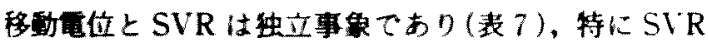
は5国が正常であるにもかかからず，音像移動奄位が 異常である所見泣，雨者が部分的に異なった中枢経路 を通る可能性を示している。これらの事実より，SVR

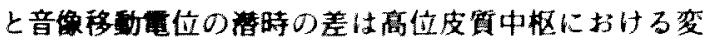
化成の自到検出に要する時間と推定できる。一方，音

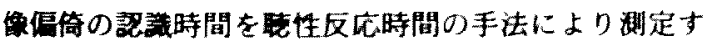

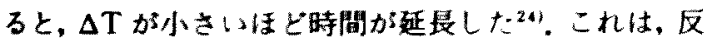

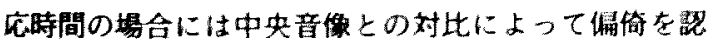

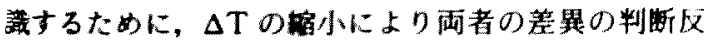

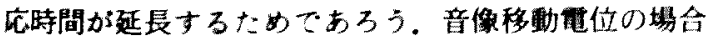
はこの前段階であり，無意諘下にバターン証識と同様 な根序に上る、变化量とは無閶保な一定の梌出時間を 高位皮質中枢において要する6のと思われる。

\section{桔䣨}

イヤホンにより両耳に連続雑音を㮦取させ，両耳間 時間差のみにより音像を急鹳に変化するとをに，頭皮 上に記録される事象関連電位を音像移動䉓位と称し て、その特性を研究した。

1. 音像移動電位はSVRに類似した 3 相性の緩徐 波であり，音像移野電位の N1 潜時はSVRのそれよ り約 $20 \mathrm{msec}$ ，延長した。
2. 音像移動電位に及代す音源の周波数条件，およ ひ時間差の影辢は，音響心理学的方法による方向感検 盁におけるそれらと近似していた。前者は“ignore”の 状照で記録されるので，方向感椮査の他賞的測定方法 として的床適応用の可能性がある。

3、音像移的電位は刺梅条件の変化により，掁幅は 変化するが，潜時は変わらなかった。この現象に基ゔ いて, Bergeijk の方向感理論により音像移動䉓位の成 立機陪を論じた。

\section{女嗝}

1) Halliday R, Callaway E: Time shift evoked potentials (TSEPs): Method and basic results. Electroenceph clin Neurophysiol 45: 118-121, 1978.

2) Ungan $P$, Sahinoğlu $B$, Utkuçal R: Human laterality reversal audiotory evoked potentials : stimulation by reversing the interaural delay of dichotically presented continuous click trains. Electroenceph clin neurophysiol 73: 306-321, 1989.

3) McEvoy LK, Picton TW, Champagne SC, Kellett AJC, Kelly JB: Human evoked potentials to shifts in the lateralization of a noise. Audiology 29: 163 $-180,1990$.

4) McEvoy LK, Picton TW, Champagne SC: Effects of stimulus parameters on human evoked potentials 
to shifts in the lateralization of a noise. Audiology $30: 286-302,1991$.

5) Jones SJ, Pitman JR, Halliday AM: Scalp poten. tials following sudden coherence and discoherence of binaural noise and change in the inter-aural time difference: a specific binaual evoked potential or a "mismatch" response? Electroenceph clin Neuro. physiol 80: 146-154, 1991 .

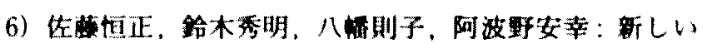

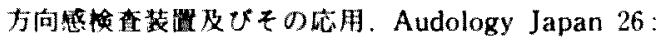
659666.1983.

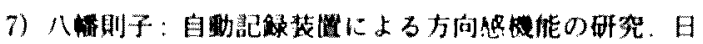
耳. $90: 376 \sim 390,1987$.

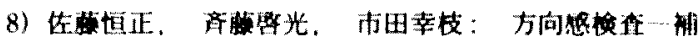
ill-Audiology Japan 29:689-690, 1985.

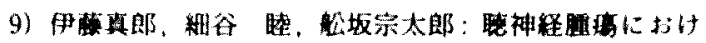

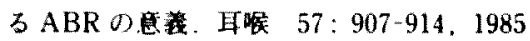

10) Paavilainen $P$, Karlsson $M L$, Reinikainen $K$, Năătänen $R$ : Mismatch negativity to change in spatial location of an audiotory stimulus. Electroenceph clin Neurophysiol 73: 129-141, 1989

11) van Bergeijk WA: Variation on a theme of Bekesy: A model of binaural interacion. J Acoust Soc Amer 34: 1431-1437, 1962.

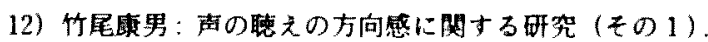
日耳焦 $67: 106-117,1964$.

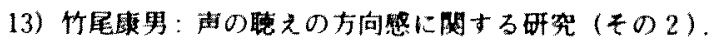
日耳年 $67: 1271-1283,1964$.

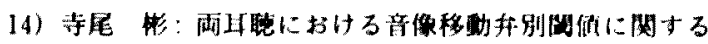
研究。日H 67：982-991，1964。

15) Naatănen R, Gaillard A WK. Mantysalo S: Eary selective-attention effect reinterpreted. Acuta Psychol(Amsu) 42: 313 329, 1978.

16) Naatanen R, Picton TW: The N1 wave of the fuman elecric and magnetic response to sound: a review and an analysis of the component structure. Psychology 24 : 375-425, 1987.

17) Bekesy Gr: Zur Theorie des Horens. Uber das Richtungshören bei einer Zeitdifferenz oder Laut. strakenungleichheit des beiderseitigen Schallein -wirkungen. Physik Z 31: 824-835, 1930.

18) Matzker J, Welker H : Die Prutung des Richtung. shorens zum Nachweis und zur topischem Dianostik von Hirnekrankungen. Z Laryngol 38: 277-294, 1959.

19) Jeffress LA, MxFadden D : Differences of interaural phase and level in detection and lateralization. J Acoust Soc Amer 49: 1169-1179, 1971.

20) van Bergeijk WA: Variation on a theme of Bekesy: A model of binaural interaction. J Acoust Soc Amer 34: 1431-1437, 1962.

21) van Bergeijk WA: Physiology psychophysics of binaural hearing. Int Audiology 3: 174-185, 1964.

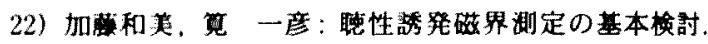
日本音学会衈觉研究会料 H-89-46, 1989.

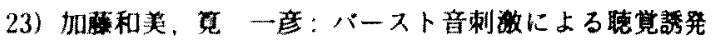

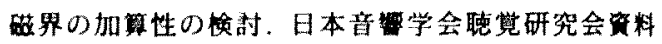
H-19-17s 1991 .

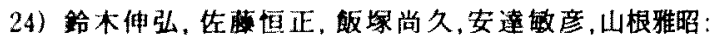

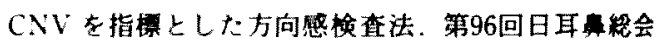
予稿集：119面，1995.

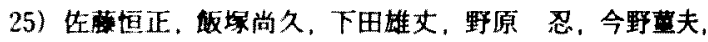

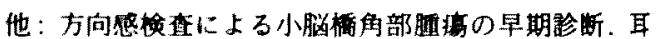
蔡床 $87: 9-22,1994$.

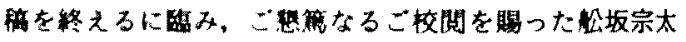

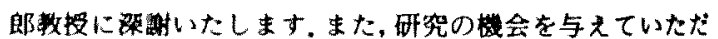

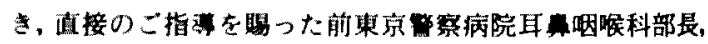

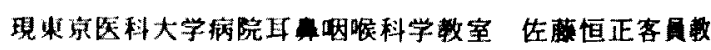

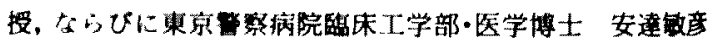

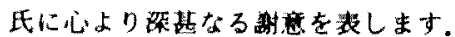

本研究の一部山，第38，39回日本聴觉医学会螕会, 第95回

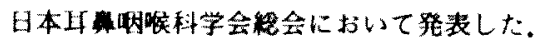

(1995年8月2日受稿 1995年11月15日受理)

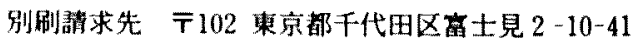

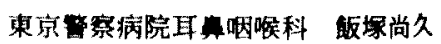




\begin{tabular}{|c|c|c|c|c|c|c|c|c|c|c|c|c|c|c|c|c|c|c|c|c|c|}
\hline 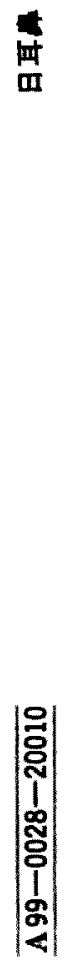 & 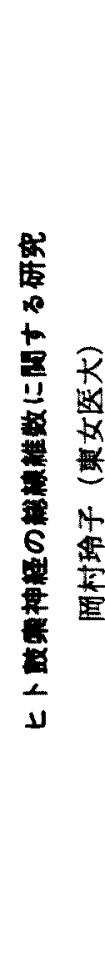 & 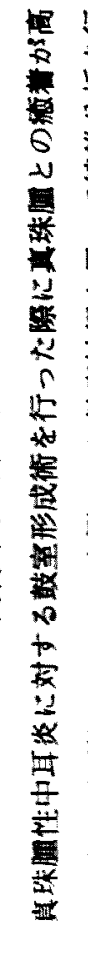 & 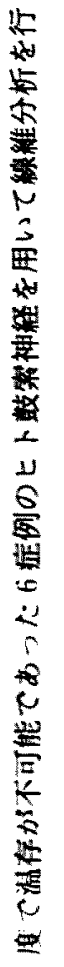 & 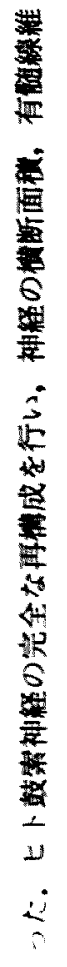 & 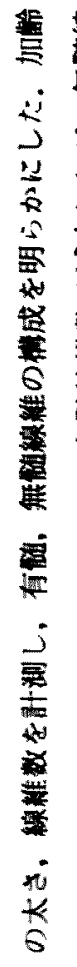 & 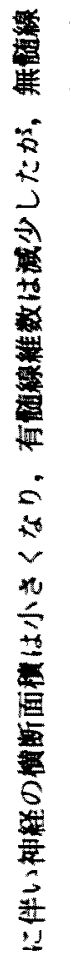 & 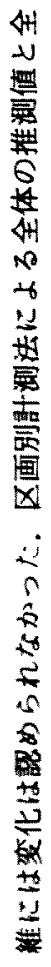 & 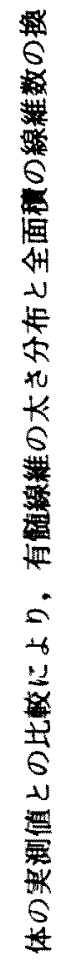 & 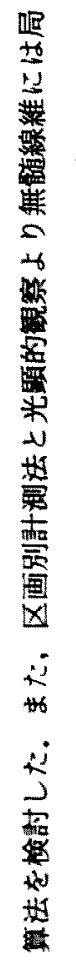 & 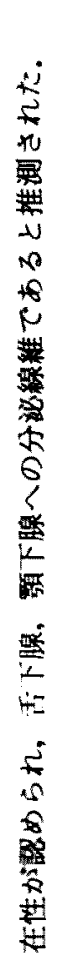 & 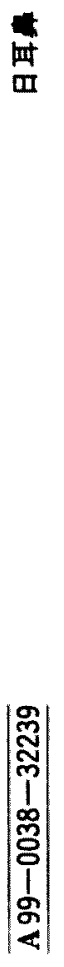 & 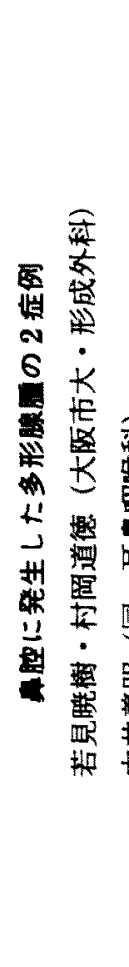 & 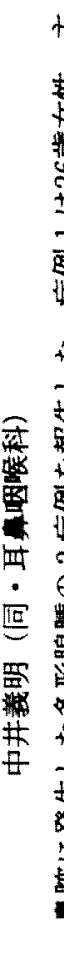 & 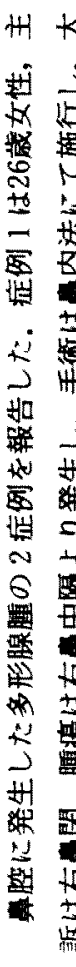 & 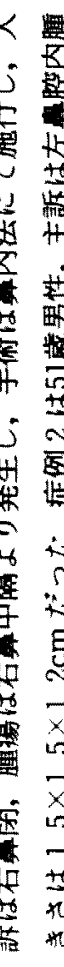 & 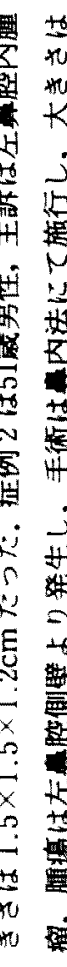 & 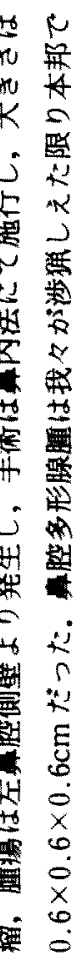 & 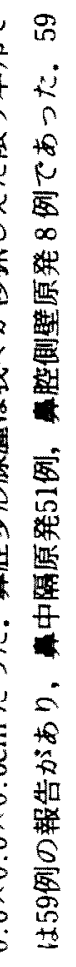 & 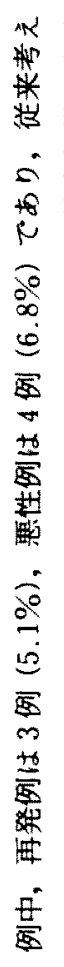 & 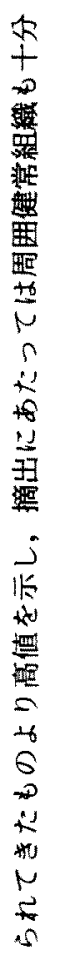 & 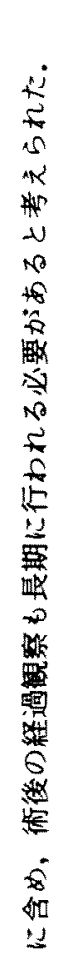 \\
\hline 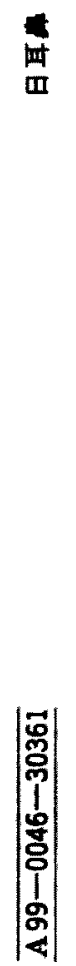 & 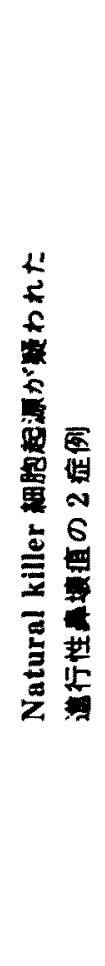 & 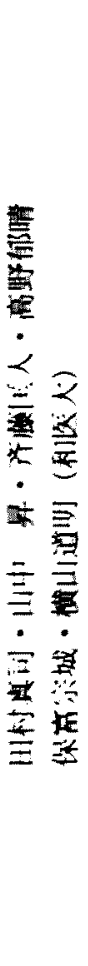 & 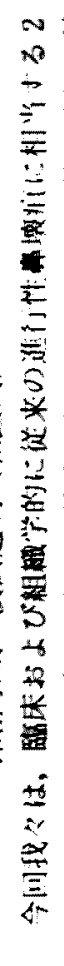 & 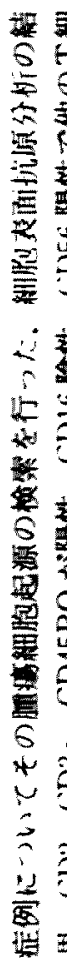 & $\begin{array}{l}7 \\
8 \\
8 \\
8 \\
8\end{array}$ & 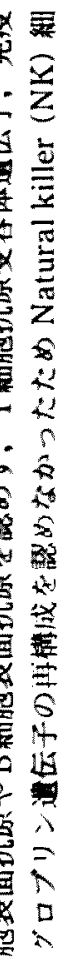 & 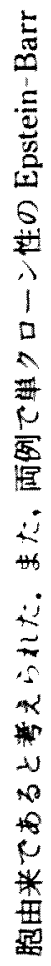 & 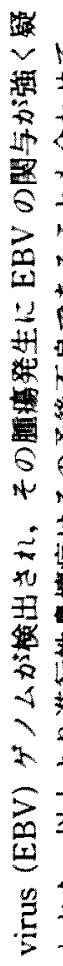 & 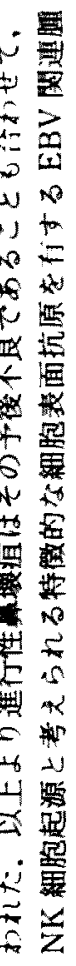 & 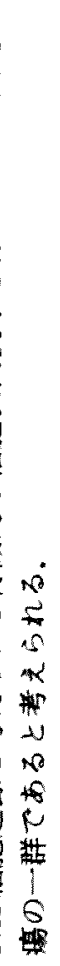 & 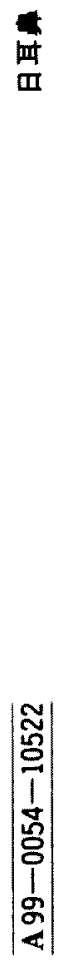 & 梁 & 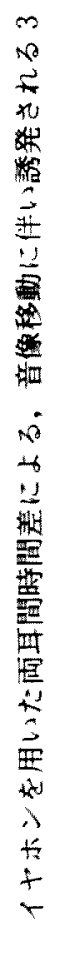 & 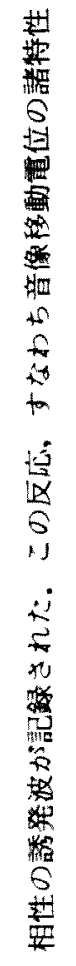 & 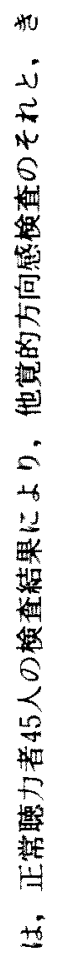 & 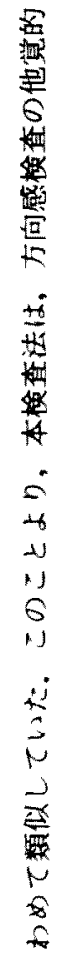 & 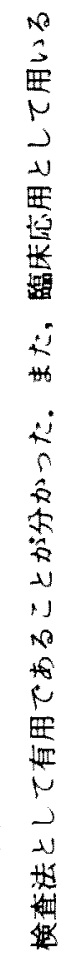 & 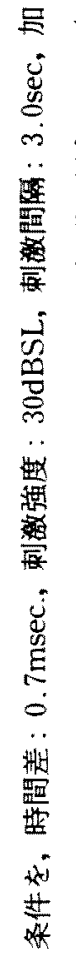 & 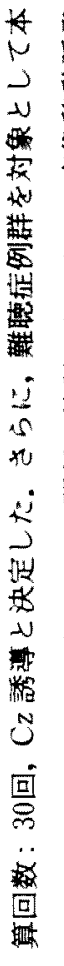 & 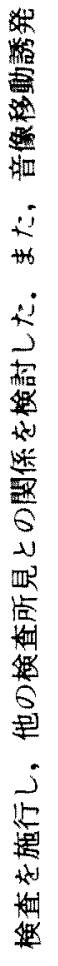 & 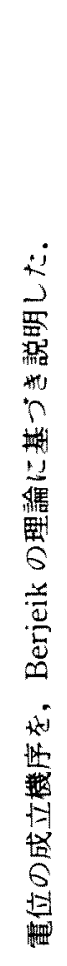 \\
\hline
\end{tabular}

